\title{
Workshop Meningkatkan Kualitas Pengasuhan dan Keterampilan Orang Tua Dalam Pengasuhan Dan Pembinaan Tumbuh Kembang Anak
}

\author{
Eneng Garnika \\ Dosen IKIP Mataram \\ enenggarnika@ikipmataram.ac.id
}

\begin{abstract}
Abstrak; Oarang tua merupakan guru pertama dan utama, namun tidak ada sekolahan khusus untuk menjadi orang tua. Orang tua harus mau dan terus belajar untuk menerapkan pola asuh yang positif pada anak, sehingga dapat membentuk karakter positif masa selanjutnya. Ilmu pengasuhan dapat diperoleh dari berbagai sumber, seperti: seminar, workshop, pelatihan, buku-buku bacaan tentang pola asuh dan media lainnya. Pada dasarnya ada enam pilar penting dalam pengasuhan anak, antara lain: kemitraan/kerjasama ayah dan ibu, 4B (belailah, bicaralah, bermain dan berpikir), kesepakatan orang tua dan anak, memahami emosi anak, gaya bahasa positif, pola asuh tanpa hukuman. Pola pikir para ayah masa kini sudah mulai bergeser dan berannggapan bahwa mencari nafkah bukan tugas satu-satunya. Peran ayah dalam mendidik dan mengasuh anak sangat besar, keterlibatan ayah dalam mengasuh anak sangat penting dan dapat memberikan konstribusi positif bagi anak dalam kehidupan selanjutnya. Beberapa hal yang akan dimiliki anak saat ayah ikut andil dalam mengasuh anak, antara lain: lebih percaya diri, lebih pintar, berani mengambil resiko, pandai bergaul, lebih disiplin, berani mencoba hal baru, lebih toleran dan pengertian, lebih aktif, lebih kreatif dan lebih spontan.
\end{abstract}

Kata Kunci: Kualitas Pengasuhan, Keterampilan Orang Tua, Pembinaan

\section{PENDAHULUAN}

Dalam rangka ikhtiar BKKBN

meningkatkan kualitas pengetahuan dan keterampilan orang tua dalam pengasuhan dan tumbuh kembang anak, maka BKKBN melibatkan berbagai sektor yang diintegrasikan dalam program layanan anak usia dini agar anak mendapatkan pelayanan secara utuh. Salah satu bentuk ikhtiar melalui pemberian pengetahuan dan pemahaman tentang pola pengasuhan kepada semua sektor terkait. Melalui sektor terkait diharapkan dapat meneruskan informasi dan pengetahuan penting dalam pengasuhan yang harus dilakukan oleh orang tua.

Orang tua merupakan pendidik utama dan pertama dirumah yang sebagai sekolah utama dan pertama bagi anak-anak. Orang tua dalam hal ini adalah ayah dan ibu, untuk menjadi ayah dan ibu tidak ada sekolahnya namun perannya sangat besar. Orang tua harus mau dan terus belajar untuk menerapkan pola asuh yang positif pada anak, sehingga dapat membentuk karakter positif masa selanjutnya. Ilmu pengasuhan dapat diperoleh dari berbagai sumber, seperti: seminar, workshop, pelatihan, buku-buku bacaan tentang pola asuh dan media lainnya. Pada dasarnya ada enam pilar penting dalam pengasuhan anak, antara lain: kemitraan/kerjasama ayah dan ibu, 4B (belailah, bicaralah, bermain dan berpikir), kesepakatan orang tua dan anak, memahami emosi anak, gaya bahasa positif, pola asuh tanpa hukuman.

Pola pikir para ayah masa kini sudah mulai bergeser dan berannggapan bahwa mencari nafkah bukan tugas satu-satunya. Peran ayah dalam mendidik dan mengasuh anak sangat besar, keterlibatan ayah dalam mengasuh anak sangat penting dan dapat memberikan konstribusi positif bagi anak dalam kehidupan selanjutnya. Beberapa hal yang akan dimiliki anak saat ayah ikut andil dalam mengasuh anak, antara lain: lebih percaya diri, lebih pintar, berani mengambil resiko, pandai bergaul, lebih disiplin, berani mencoba hal baru, lebih toleran dan pengertian, lebih aktif, lebih kreatif dan lebih spontan.

Pada masa balita hampir seluruh selsel otak berkembang pesat, tidak ada orang 
yang paling berarti dalam kehidupannya selain orang tuanya (ayah ibunya). Ayah Ibu merupakan orang yang dapat memenuhi segala pertumbuhannya. Kemampuan orang tua dalam memenuhi kebutuhan anak akan asih, asah dan asuh melalui komunikasi yang baik dan benar, akan mempengaruhi mutu atau kualitas kepribadian anak menuju manusia dewasa di kemudian hari. Orang tua mempunyai peran yang sangat penting dalam menentukan arah serta mutu pertumbuhan dan perkembangan anak.

\section{TARGET DAN LUARAN}

\section{A. Target Program}

Program ini memiliki target sebagai berikut:

1. Program ini diperuntukan bagi mitra BKKBN di Nusa Tenggara Barat.

2. Memberi pemahaman dan pengalaman belajar bagi para mitra tentang pentingnya pola asuh positif dalam menjalankan 8 fungsi keluarga.

3. Berbagi pengalaman kepada para mitra dan membangun kesadaran para orang tua untuk menerapkan pola asuh positif.

\section{B. Luaran Program}

Kegiatan ini dapat meningkatkan pengetahuan, pemahaman dan kesadaran para mitra pelaksana lapangan BKKBN dan para orang tua dalam melakukan pengasuhan positif pada anak.

\section{METODE PELAKSANAAN}

A. Mekanisme Pelaksanaan

1. Menerima Permohonan dan Mendapatkan Tugas Menjadi Narasumber Dari Dekan FIP IKIP Mataram.

2. Melaksanakan tugas menjadi narasumber dalam kegiatan Workshop yang diselenggarakan oleh BKKBN Provinsi NTB. Dalam melaksanakan tugas menggunakan beberapa metode, antara lain: ceramah, diskusi dan daur pengalaman.

\section{B. Rencana Keberlanjutan Program}

Program ini akan berlanjut dengan kegiatankegiatan lainnya yang diselenggarakan secara konsisten dan berkelanjutan sebagai salah satu program untam BKKBN.

\section{HASIL KEGIATAN}

Kegiatan ini dilaksanakan melalui presentasi/ceramah, diskusi dan daur pengalaman. Materi disampaikan secara individu oleh diberi tugas oleh Dekan Fakultas Ilmu Pendidikan IKIP Mataram.Materi yang disampaikan terkait dengan keterlibatan seorang ayah dalam pengasuhan dalam bentuk power point dengan penjelasan secara teori dan konsep serta diberi contoh kongkrit sebagai penguat. Seluruh peserta selain belajar dari pemateri juga mendapat kesempatan belajar dari peserta yang aktif bertanya serta mau berbagi pengalaman tentang pengasuhan baik yang sifatnya negatif maupun yang positif.

Metode daur pengalaman digunakan untuk proses pembelajaran orang dewasa yang cukup efektif dilaksanakan. Peserta menjadi lebih paham ketika mendapatan informasi secara konsep dan diperkuat dengan pengalaman. Pada umumnya peserta masih banyak yang belum memahami bagaimana pengasuhan yang positif dan dampak dari keterlibatan seorang ayah dalam pengasuhan. Di Provinsi Nusa Tenggara Barat pada umumnya berdasarkan informasi dari seluruh peserta bahwa masih banyak para ayah yang belum mau terlibat dalam pengasuhan, Pola pikir lama yang masih terbawa sampai saat ini bahwa pengasuhan menjadi tanggungjawab seorang ibu, membuat para ayah belum terlibat dalam pengasuhan.

Respon peserta sangat baik dan cukup antusias saat disampaikan bahwa apabila seorang ayah terlibat dalam pengasuhan banyak manfaat yang diperoleh oleh anak. Manfaat dari keterlibatan ayah dalam pengasuhan antara lain: lebih percaya diri, lebih pintar, berani mengambil resiko, pandai bergaul, lebih disiplin, berani mencoba hal baru, lebih toleran dan pengertian, lebih aktif, lebih kreatif serta lebih spontan. 


\section{Contoh Daftar Pertanyaan Dari Peserta:}

\begin{tabular}{|c|c|c|c|}
\hline No & Penanya & Pertanyaan & Jawaban Narasumber \\
\hline 1. & Murni & $\begin{array}{l}\text { Pola asuh yang bagaimana } \\
\text { yang cocok digunakan untuk } \\
\text { anak-anak yang tidak bisa } \\
\text { lepas dari telepon genggam. }\end{array}$ & $\begin{array}{l}\text { Pola asuh demokratis memungkinkan } \\
\text { orang tua dan anak saling menyesuaikan } \\
\text { dengan berbagai keadaan dirinya. Pola } \\
\text { asuh demokratis, memprioritaskan } \\
\text { kepentingan anak, tetapi tidak ragu } \\
\text { dalam mengendalikan anak. Orang tua } \\
\text { seperti ini bersikap tegas, rasional dan } \\
\text { selalu mendasari tindakannya pada } \\
\text { pemikiran. Anak diajak berdiskusi } \\
\text { tentang dampak dari penggunaan telepon } \\
\text { genggam dan beri pemahaman secara } \\
\text { tuntas serta penuh kesabaran sehingga } \\
\text { anak menjadi paham dampaknya dan } \\
\text { menemukan jawaban serta } \\
\text { menyimpulkan sendiri harus bagaimana } \\
\text { saat menggunakan telepon genggam } \\
\text { terutama hal waktu yang digunakan dan } \\
\text { konten yang boleh dilihat. }\end{array}$ \\
\hline 2. & Ida & $\begin{array}{l}\text { Apakah tidak berdosa kalau } \\
\text { kita sebagai istri nyuruh } \\
\text { suami untuk jagain anak, } \\
\text { sementara pengasuhan anak } \\
\text { itu tanggungjawab seorang } \\
\text { ibu. }\end{array}$ & $\begin{array}{l}\text { Anak itu merupakan titipan yang Allah } \\
\text { berikan, melalui sperma yang ayah } \\
\text { keluarkan dan dititipkan dirahim } \\
\text { seorang ibu, sehingga dari prosesnya } \\
\text { sudah menunjukan bahwa anak } \\
\text { tannggungjawab bersama yaitu ayah dan } \\
\text { ibu. Begitu juga dalam pendidikan, } \\
\text { perawatan dan pengasuhannya, sehingga } \\
\text { apabila dikomunikasikan dengan baik } \\
\text { dan sifatnya tidak menyuruh tentunya } \\
\text { tidak menjadi dosa. }\end{array}$ \\
\hline 3. & Atun & $\begin{array}{l}\text { Apa ada pengaruhnya anak } \\
\text { yang diasuh ibunya saja } \\
\text { karena ayahnya sudah tidak } \\
\text { dirumah lagi, ayahnya } \\
\text { tinggal bersama istri } \\
\text { barunya. }\end{array}$ & $\begin{array}{l}\text { Tentu ada pengaruhnya, karena sosok } \\
\text { ayah tidak dapat digantikan oleh seorang } \\
\text { ibu. Perceraian merupakan hal yang } \\
\text { tidak diinginkan oleh seorang anak dan } \\
\text { menyakitkan bagi anak. Pengasuhan } \\
\text { yang baik dilakukan bersama dan atas } \\
\text { kesepakatan bersama sehingga anak- } \\
\text { anak merasa lebih yakin mengikuti apa } \\
\text { yang disarankan oleh orangtuanya serta } \\
\text { lebih mudah mengikuti apa yang } \\
\text { diinginkan oleh kedua orangtuanya. }\end{array}$ \\
\hline
\end{tabular}

\section{SIMPULAN}

Kegiatan pengabdian pada masyarakat telah dilaksanakan dengan lancar, respon peserta sangat baik. Banyak peserta yang ingin bertanya, namun pertanyaan dibatasi hanya untuk 5 peserta, dari pertanyaan yang diajukan oleh lima penanya, membuktikan rasa ingin tahu dari para peserta cukup besar tentang pola asuh positif yang melibatkan seorang ayah dalam pengasuhannya. Seluruh peserta berharap kegiatan yang sama dapat diselenggarakan lagi.

\section{DAFTAR PUSTAKA}

Byron. T. 2009. Ensiklopedia Perkembangan Anak. Jakarta: Esensi.

Morrison. G. 2012. Dasar-Dasar Pendidikan Anak Usia Dini. Jakarta: Indeks.

Noe'man. R R. 2012. Amazing Parenting. Jakarta: PT Mizan Publika

Nutbrown. C dan Clough .C. 2014. Pendidikan Anak Usia Dini.

Yogyakarta: Pustaka Pelajar

Yamin.M dan Sabri.J. 2012. Panduan Pendidikan Anak Usia Dini. Jakarta: Gaung Persada Press Group.

Yuliani NS. 2012. Konsep Dasar Pendidikan Anak Usia Dini. Jakarta: Indeks.

Ratuliu. M. 2017. ParenThink. Jakarta: Noura Books.

Semmelroth.C. 2008. The Anger Habit In Parenting. Bandung: Kaifa.

-------. 2014. Menjadi Orang Tua Hebat Dalam Mengasuh Anak (Usia 0-6 tahun). Badan Kependudukan Dan Keluarga Berencana Nasional.

--------. 2017. Menjadi Orang Tua Hebat Dalam Mengasuh Anak (Usia 0-6 tahun). Badan Kependudukan Dan Keluarga Berencana Nasional. 